\title{
Hubungan workplace incivility dan turnover intention: efek moderasi gender
}

\author{
Hendryadi $^{1}$, Rachma Zannati ${ }^{2}$ \\ ${ }^{1}$ Manajemen, Sekolah Tinggi Ilmu Ekonomi Indonesia Jakarta. Jl. Kayu Jati Raya No.11A, \\ Rawamangun, Jakarta Timur, DKI Jakarta 13220, Indonesia \\ ${ }^{2}$ Akuntansi, Sekolah Tinggi Ilmu Ekonomi Indonesia Jakarta. Jl. Kayu Jati Raya No.11A, \\ Rawamangun, Jakarta Timur, DKI Jakarta 13220, Indonesia \\ ${ }^{1}$ Email:hendry.basrah@gmail.com \\ 2Email: rachmaznt@gmail.com
}

\begin{abstract}
Abstrak
Penelitian ini bertujuan untuk mengetahui hubungan antara workplace incivility (WIC) dengan niat keluar (turnover intention), efek moderasi gender pada hubungan WIC dengan niat keluar, dan perbedaan WIC berdasarkan gender. Sebanyak 300 responden (52\% wanita) dari berbagai perusahaan mengisi kuesioner. Pengujian hipotesis menggunakan independent t-test, dan regresi hierarki moderasi. Hasil penelitian mengungkapkan bahwa WIC berhubungan positif terhadap niat keluar, dan gender tidak terbukti sebagai moderator pada hubungan WIC dan niat keluar. Terakhir, hasil menyimpulkan bahwa ada perbedaan tingkat WIC berdasarkan gender, dan diluar dugaan, karyawan pria memiliki tingkat WIC lebih tinggi dibanding karyawan wanita. Penelitian ini dapat bermanfaat bagi para manajer dan organisasi untuk mengidentifikasi, mencegah dan mengelola perilaku menyimpang karyawan di tempat kerja secara lebih efektif.
\end{abstract}

Kata Kunci: workplace incivility; gender; turnover intention

\section{Workplace incivility relations and turnover intention: gender moderation effects}

\begin{abstract}
The aim of the study was to investigate the relationship between workplace incivility (WIC) and attitude characterized by turnover intention, examine whether gender moderates the relationship and the differences in WIC acceptance between male and female employees. Survey participants included 300 employees (52\% females) who completed a self-administrated questionnaire. Hypothesis testing uses the independent $t$-test and regression hierarchy moderation. The results revealed that WIC was positively related to intention turnover, and gender is not supported as moderator of the incivilityturnover intention relationship. Finally, there was a significant difference in WIC between males and females. Unexpectedly, males perceived more high levels of WIC than females. This research can be useful information for managers to identify, prevent, and manage deviant behavior in the workplace more effectively.
\end{abstract}

Keywords: workplace incivility; gender; turnover intention 


\section{PENDAHULUAN}

Sepanjang satu dekade terakhir isu perilaku ketidaksopanan di tempat kerja (workplace incivility) telah banyak mendapatkan perhatian praktisi manajemen. Berbagai laporan memperlihatkan bahwa fenomena ini mengalami tren peningkatan dan semakin mengkhawatirkan dalam lingkungan kerja. Perilaku incivil di tempat kerja seperti berkurangnya penghargaan kepada sesama rekan (misalnya sekedar mengucapkan terimakasih atas bantuan sederhana yang diberikan), atau meminta tolong dengan kata-kata sopan kepada bawahan merupakan bentuk sederhana bagaimana kita menghargai orang-orang di sekitar. Contoh lain dari perilaku ini termasuk tindakan seperti menggunakan bahasa yang merendahkan, membuat ancaman terselubung, bergosip, mengabaikan permintaan rekan kerja, atau sebaliknya menunjukkan ketidakhormatan terhadap orang lain di tempat kerja (Holm et al., 2015; Reich dan Hershcovis, 2015). Krisis incivility dianggap sebagai sebuah benturan budaya, dimana orang-orang dengan latar belakang budaya yang berbeda bertemu dalam satu komunitas atau organisasi. Adanya perbedaan pandangan mengenai norma-norma kesopanan sehingga banyak generasi kerja yang lebih tua sekarang menganggap generasi muda sebagai orang-orang yang kasar, tidak berbudaya dan tidak memiliki etika kerja (Leiter et al. 2010).

Literatur pada ilmu manajemen menunjukkan bahwa ketidaksopanan merupakan hal yang tidak bisa dipungkiri terjadi dalam organisasi modern dan hampir di semua industri. Pearson dan Porath, merupakan dua peneliti yang secara intensif melakukan kajian mengenai workplace incivility di tahun 2009 melaporkan bahwa 96\% karyawan yang disurvey mengalami perilaku tidak sopan di tempat kerja, dan 99\% menyatakan pernah menjadi saksi atas peristiwa ini. Pada tahun 2011, hasil survey mereka menyebutkan $98 \%$ karyawan mengalami perilaku tidak sopan, dan setengah dari responden mengatakan bahwa mereka diperlakukan dengan kasar setidaknya sekali seminggu. Lewis dan Malecka di tahun yang sama melaporkan bahwa hampir $85 \%$ responden yang merupakan perawat pernah mengalami perilaku incivil dalam 12 bulan terakhir. Sebelumnya, dalam penelitian terhadap lebih dari 1000 pekerja layanan sipil A.S., Cortina, Magley, Williams, dan Langhout (2001) menemukan bahwa lebih dari 70\% sampel mengalami perilaku tidak sopan ini. Penelitian lain menunjukkan bahwa 71 persen pegawai pengadilan, 75 persen karyawan universitas, 79 persen pegawai penegak hukum, dan 85 persen perawat mengalami ketidaksopanan di tempat kerja (Cortina dan Magley, 2009; Lewis dan Malecha, 2011).

Incivility dalam kajian perilaku organisasi merupakan salah satu bentuk perilaku menyimpang (deviant behavior). Workplace incivility dapat diartikan sebagai perilaku dengan intensitas rendah yang tidak memiliki maksud yang jelas untuk menyakiti, namun tetap melanggar norma sosial dan menyakiti perasaan karyawan yang ditargetkan (Andersson \& Pearson, 1999:p.457). Studi-studi sebelumnya memberikan bukti bahwa penting untuk mempelajari perilaku ketidaksopanan karena dapat memberikan efek negative pada sikap karyawan, seperti penarikan kerja (Lim et al., 2008; Pearson dan Porath, 2009; Loi et al. 2013). Penarikan kerja mengacu kepada perilaku mengurangi waktu dan usaha untuk menyelesaikan pekerjaan. Ini termasuk tidak bersedia bekerja lembur, beristirahat lebih lama, atau mengambil cuti sakit padahal tidak benar-benar sakit (Andersson dan Pearson, 1999; Cortina et al., 2001; Lim dan Cortina, 2005; Pearson dan Porath, 2009). Pearson dan Porath (2005) menemukan bahwa karyawan yang menjadi korban perilaku ketidaksopanan tempat kerja mengurangi upaya kerja mereka dan ini akhirnya mengurangi kualitas pekerjaan mereka.

Penelitian yang lebih baru menemukan hubungan positif antara ketidaksopanan dan perilaku kerja kontraproduktif seperti penyalahgunaan, penyimpangan produksi, sabotase, pencurian, dan penarikan (Bibi et al. 2013). Penelitian lain melaporkan bahwa ketidaksopanan dikaitkan dengan ketidakhadiran, tingkat kemarahan, ketakutan, dan kesedihan yang lebih tinggi di tempat kerja (Porath dan Pearson, 2012), ketidakpuasan kerja, dan kelelahan (Welbourne et al., 2015; Kim et al., 2013; Rahim dan Cosby, 2016), tingkat stres yang lebih tinggi (Beattie dan Griffin, 2014), mengurangi kreativitas (Porath dan Enez, 2009), mengurangi retensi (Lim et al., 2008), dan turnover intention (Cortina et al., 2002; Reio and Trudel, 2013; Rahim dan Cosby, 2016). Ketidaksopanan juga secara langsung berhubungan dengan produktivitas (Lewis dan Melecha, 2011; Rahim dan Cosby, 2016). Meskipun sudah mendapatkan perhatian yang luas dari peneliti dan akademisi, isu incivility lebih banyak diteliti di sektor kesehatan, sosial dan pendidikan di negara-negara Eropa dan Amerika, dan relative terbatas di Asia, terutama di Indonesia. 
Selain adanya perbedaan wilayah penelitian yang kemungkikan memberikan hasil berbeda karena adanya perbedaan nilai budaya, penelitian yang mencoba menjelaskan perbedaan perilaku incivility berdasarkan gender yang masih menjadi perdebatan. Beberapa penelitian dan teori menunjukkan bahwa gender adalah faktor yang dapat membedakan persepsi, penerimaan, dan dampak ketidaksopanan di lingkungan kerja. Wanita lebih mungkin menjadi target perilaku tidak sopan di tempat kerja dibanding laki-laki (Welbourne et al. 2015; Miner dan Eischeid, 2012; Loi et al. 2013; Cortina, 2008). Menurut pemikiran ini, wanita dianggap lebih peka terhadap perilaku sosial dibanding pria. Konsekuensinya adalah mereka lebih mungkin menghadapi masalah interpersonal dibandingkan laki-laki seperti ketidaksopanan di tempat kerja. Berbeda dengan penelitian tersebut, Pearson dan Porath (2005) menemukan bahwa pria dan perempuan sama-sama cenderung dapat menjadi korban ketidaksopanan di tempat kerja. Kesimpulan yang sama juga dinyatakan oleh Hutton dan Gates (2008) yang tidak menemukan hubungan antara faktor demografi (misalnya jenis pekerjaan, pendidikan, suku, gender) pada tingkat ketidaksopanan di tempat kerja. Peneliti lain tidak menemukan hubungan antara ketidaksopanan tempat kerja dan demografi. Karena adanya perbedaan tersebut maka perlu dilakukan pengujian ulang untuk mengklarifikasi hubungan incivility dengan gender.

Tujuan pertama penelitian adalah menguji hubungan antara workplace incivility dan niat karyawan keluar atau mengundurkan diri dari pekerjaan. Cortina (2008) menyatakan bahwa ketidaksopanan dapat memiliki bias yang lebih sering diarahkan pada wanita (Welbourne et al. 2015; Miner dan Eischeid, 2012; Loi et al. 2013). Untuk alasan ini, tujuan kedua dari penelitian ini adalah untuk menguji peran gender sebagai moderator hubungan workplace incivility dan turnover intention, sekaligus memeriksa perbedaan level atau tingkat yang dirasakan oleh laki-laki dan wanita pada perilaku incivil untuk menentukan apakah ketidaksopanan dapat mencerminkan merupakan bentuk diskriminasi gender. Selain dapat memberikan bukti empiris baru, penelitian ini dapat berkontribusi untuk menutupi gap perbedaan hasil penelitian sebelumnya. Dari isi praktis, penelitian ini dapat menjadi informasi yang bermanfaat bagi manajer di Indonesia untuk dapat mengelola perilaku penyimpang di tempat kerja secara lebih efektif.

\section{Workplace incivility: konsep dan teori}

Teori modal sosial (social capital theory) merupakan kerangka kerja untuk penelitian ini, dimana perubahan positif terjadi ketika hubungan sosial dalam komunitas efektif dan berjalan baik. Efektif dan kebaikan ini mengandung adanya kepercayaan, timbal balik, kolaborasi, dan kerja sama, dan interaksi antar anggota. Agar berhasil, pegawai harus menjaga kesopanan untuk membangun modal sosial dan memperkuat kolaborasi di tempat kerja (Kelly \& McAllister,2013).

Incivility merupakan salah satu bentuk perilaku menyimpang (deviant behavior). Workplace incivility dapat diartikan sebagai perilaku dengan intensitas rendah yang tidak memiliki maksud yang jelas untuk menyakiti, namun tetap melanggar norma sosial dan menyakiti perasaan karyawan yang ditargetkan (Pearson dan Porath, 1999). Dengan kata lain, ketidaksopanan tempat kerja dapat berupa pertukaran kata-kata dan perbuatan yang tampaknya tidak penting namun tetap melanggar norma perilaku kerja (Pearson dan Porath, 2009). Ketidaksopanan juga digambarkan sebagai perlakuan yang tidak sopan, kasar, tidak sabar, atau menunjukkan kurangnya penghargaan atau penghormatan pada martabat orang lain. Akibatnya, karyawan yang mendapatkan perlakuan mengalami penurunan komitmen dari waktu ke waktu (Montgomery et al., 2004). Contoh dari beberapa perilaku tidak sopan ini termasuk tidak mengucapkan terima kasih, gosip umum, mengalihkan pandangan pada saran rekan kerja, mengirim SMS atau mengirim email selama rapat, membuat komentar yang merendahkan, dan mengabaikan atau menghina rekan kerja (Pearson dan Porath, 2009).

Tabel 1. Bentuk workplace incivility

\begin{tabular}{|c|c|}
\hline Subtle/covert (terselubung) & Overt (terbuka) \\
\hline $\begin{array}{l}\text { Meminta masukan dan kemudian mengabaikannya, } \\
\text { Tidak menghargai kontribusi orang lain dalam team, } \\
\text { Memberi seseorang "tatapan kotor"/ merendahkan, } \\
\text { Tidak mendengarkan percakapan selama } \\
\text { pertemuan/presentasi bisnis formal, } \\
\text { Berbicara tentang seseorang di belakang (Gosip), } \\
\text { berbicara dengan nada merendahkan, }\end{array}$ & $\begin{array}{l}\text { Mengabaikan pekerja dengan komentar, isyarat atau } \\
\text { perilaku yang tidak layak (perilaku bermusuhan) } \\
\text { berdasarkan karakteristik seperti ras, agama, jenis } \\
\text { kelamin, dan lain-lain. Hal ini dianggap sebagai } \\
\text { diskriminasi di tempat kerja, } \\
\text { Mengganggu pertemuan, } \\
\text { Memberi teguran di depan publik, }\end{array}$ \\
\hline
\end{tabular}




\begin{tabular}{l|l}
\hline Tidak mengajak rekan dalam pertemuan penting, \\
$\begin{array}{l}\text { Membuka atau memeriksa PC/Laci rekan } \\
\text { kerja/bawahan tanpa ijin, dan lainnya. }\end{array}$ & $\begin{array}{l}\text { Mendiamkan, atau menghina orang lain, } \\
\text { Membuat tuduhan tentang kompetensi professional, } \\
\text { Mengabaikan keputusan tanpa memberi alasan, } \\
\text { Meruntuhkan kredibilitas di depan orang lain, dan } \\
\text { lainnya. }\end{array}$ \\
\hline
\end{tabular}

Sumber: Pearson dan Porath, (1999), Pearson dan Porath, (2009); Montgomery et al., (2004)

\section{Workplace incivility dan turnover intention}

Perputaran karyawan (turnover) mengacu pada fenomena karyawan meninggalkan organisasi secara sukarela (Shaw et al., 2005). Keputusan karyawan untuk meninggalkan organisasi sangat mahal baik bagi individu maupun organisasi (Lee et al., 2004). Tiga komponen dasar umumnya dipertimbangkan ketika menghitung biaya perputaran karyawan, termasuk biaya rekrutment, biaya penggantian, dan biaya pelatihan (Cascio, 2000). Menurut beberapa peneliti, ketidaksopanan tempat kerja mengarah ke perilaku yang lebih kasar dan agresif (Andersson \& Pearson, 1999). Andersson dan Pearson (1999) juga berpendapat bahwa ketidaksopanan dapat menyebabkan reaksi serupa dari pihak lain atau mengarah ke perilaku yang lebih serius. Ini dapat mengarah pada bentuk pembalasan dan memprovokasi tindakan yang lebih serius di pihak lain. Situasi semacam itu akan mengarah pada bentuk-bentuk ekstrim perilaku kerja yang kontraproduktif, yang dapat mengakibatkan agresi atau kekerasan.

Para peneliti juga telah menemukan ketidaksopanan tempat kerja berhubungan negatif dengan produktivitas dan kepuasan kerja, dan berhubungan positif dengan ketidakhadiran, keterlambatan, dan keinginan berpindah (Lim \& Cortina, 2005; Penney \& Spector, 2005; Rahim \& Cosby, 2015).Hansen (1993) menemukan bukti bahwa korban perilaku tidak sopan di tempat kerja cenderung mempertimbangkan secara sukarela meninggalkan organisasi atau secara sukarela mengundurkan diri dari perusahaan. Dengan kata lain ketidaksopanan mengarah pada niat untuk mengundurkan diri (Rahim dan Cosby, 2015).

$\mathrm{H} 1$ : workplace incivility berhubungan positif dengan turnover intention

\section{Demografi dan workplace incivility}

Demografi adalah karakteristik karyawan yang membedakannya dengan karyawan lain. Unsur demografi dapat berupa usia, jenis kelamin, pendidikan, masa kerja, dan faktor-faktor sosial lainnya. Sejumlah peneliti telah berteori bahwa apa yang dianggap ofensif atau tidak dapat bervariasi berdasarkan gender. Menurut garis pemikiran ini, wanita cenderung lebih peka terhadap nuansa perilaku sosial dibanding pria. Konsekuensinya, mereka mungkin lebih sering dibanding pria menghadapi masalah interpersonal seperti ketidaksopanan di tempat kerja. Sejumlah penelitian memang menemukan bahwa perempuan secara konsisten menilai secara potensial perilaku tidak sopan atau melecehkan di tempat kerja sebagai lebih ofensif, tidak pantas atau menghina daripada laki-laki (Montgomery et al., 2004). Sebaliknya, Pearson dan Porath (2005) menemukan bahwa perempuan lebih mungkin terkena ketidaksponan daripada laki-laki dan menjadi sasaran pelecehan.

Cortina (2008) menyarankan bahwa perilaku tidak sopan mungkin lebih sering ditargetkan pada wanita dan suku minoritas (dalam konteks Amerika). Dukungan untuk teori ini berasal dari temuan penelitian bahwa wanita mengalami lebih banyak ketidaksopanan di tempat kerja daripada pria (Cortina et al. 2001, 2002; Lim et al. 2008). Namun,sebagian besar penelitian yang membandingkan laki-laki dan perempuan menunjukkan bahwa ketidaksopanan umumnya memiliki dampak negatif yang selatif sama antara perempuan dan laki-laki (Cortina et al. 2001; Lim dkk. 2008). Riset lebih baru menemukan 65 persen wanita dibandingkan dengan 47 persen pria mengalami "ketidaksopanan umum" di tempat kerja mereka (Cortina et al., 2013). Berdasarkan uraian tersebut diajukan hipotesis sebagai berikut:

$\mathrm{H} 2$ : Gender memoderasi hubungan workplace incivility dengan turnover intention

H3: Ada perbedaan persepsi workplace incivility antara laki-laki dan wanita 


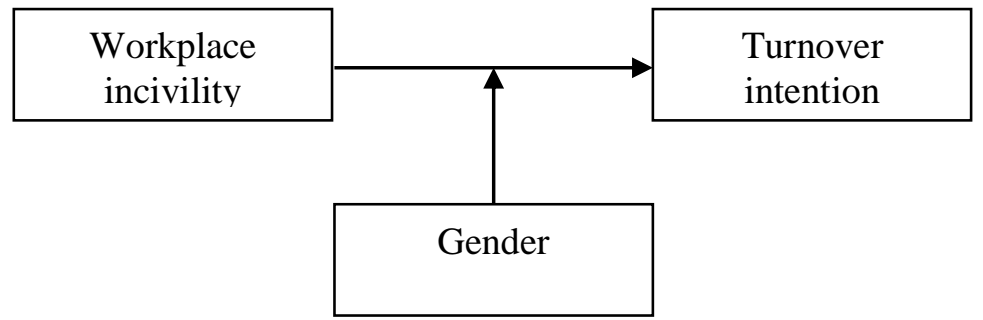

Gambar 1. Model Penelitian

Sumber: Data diolah

\section{METODE}

\section{Prosedur Sample}

Penelitian ini menggunakan metode non-probability convenience sampling untuk mendapatkan jumlah responden yang tepat untuk penelitian ini. Sebanyak 340 kuesioner didistribusikan, dan yang memiliki kelengkapan isi dan kembali sebanyak 300 kuesioner (88\%) dan digunakan sebagai data penelitian. Responden terdiri dari 156 wanita (52\%) dan 144 laki-laki (48\%). Sebanyak 168 responden $(56 \%)$ berusia kurang dari 25 tahun, dan sisanya $44 \%$ berusia di atas 25 tahun. Mayoritas responden berstatus belum menikah $(65 \%)$, dan $59 \%$ responden memiliki masa kerja kurang dari tiga tahun.

\section{Pengukuran}

Workplace incivility atau ketidaksopanan di tempat kerja. Penelitian ini menggunakan skala tujuh item yang dikembangkan oleh Cortina et al. (2001) untuk mengukur sejauh mana karyawan telah mengalami ketidaksopanan tempat kerja dalam satu tahun terakhir. Skala penilaian berkisar antara 1 ="tidak pernah", hingga $5=$ "sangat sering". Sebuah contoh item adalah "supervisor atau rekan kerja mengucapkan kata kasar kepada anda”. Skala ini telah diuji dan memiliki konsistensi internal 0.87 oleh penelitian Chen et al. (2010).

Turnover intention. Tiga item turnover intention subscale dari Skala Penilaian Organisasi Michigan (Seashore et al., 1982) digunakan untuk mengukur turnover intentions responden: (1) Saya aktif mencari pekerjaan baru; (2) Saya sering berpikir untuk berhenti; dan (3) Saya mungkin akan mencari pekerjaan baru pada tahun depan. Respon berkisar dari 1 (sangat tidak setuju) hingga 5 (sangat setuju). Kisaran skor yang mungkin adalah 3 hingga 15. Skor yang lebih tinggi pada skala menunjukkan tingkat yang lebih tinggi dari keinginan berpindah. Skala ini telah terbukti memiliki reliabilitas dan validitas yang memadai ( $\alpha=0,93$; Valle, Harris, \& Andrews, 2004) dan $\alpha=0.91$ untuk penelitian Karim et al. (2015).

Variabel kontrol. Penelitian ini menggunakan tiga variabel kontrol yaitu usia, masa kerja, dan status pernikahan. Hal ini didasarkan pada penelitian Ferriss (2002) yang memasukkan variabel umur, masa kerja, dan status pernikahan pada penelitian perilaku ketidaksopanan.

\section{Teknik Analisis}

Teknik analisis statistik inferensi digunakan untuk menguji hipotesis, yaitu hierarchical moderated regression analysisuntuk pengujian hipotesis 1 dan 2, dan independent t-test untuk pengujian hipotesis 3. Semua skala dijumlahkan untuk membentuk skor komposit. Untuk menguji efek moderasi, data mean centering digunakan untuk menghindari multikolinieritas saatmengalikan variabel moderasi (gender) dengan workplace incivility. Variance inflation factor(VIF) diuji untuk collinearity antara variabel dengan menghitung untuk masing-masing koefisien regresi, dan ini jauh di bawah nilai cut-off 10 direkomendasikan oleh Hair et al. (2006). Hipotesis diuji dengan memperkirakan persamaan berikut menggunakan analisis regresi hierarki sebagai berikut:

Model 1: $\mathrm{TURN}=\beta_{0}+\mathrm{K}_{1-3}$

Model 2: TURN $=\beta_{0}+\mathrm{K}_{1-3}+\beta_{1}$ WIC $+\beta_{2}$ GENDER

Model 3: TURN $=\beta_{0}+\mathrm{K}_{1-3}+\beta_{3}$ WIC $+\beta_{4}$ GENDER $+\beta_{5}($ WIC $*$ GENDER $)$ 


\section{HASIL DAN PEMBAHASAN}

\section{Pengujian Validitas Struktur dan Keandalan}

Tahap pertama dari analisis adalah melakukan pengujian validitas dan reliabilitas skala yang digunakan. Pendekatan uji validitas menggunakan teknik analisis faktor.Prinsip yang digunakan analisis factor adalah mengelompokkan data berdasarkan interkorelasi antar butir. Parameter pertama adalah dengan memperhatikan nilai Kaiser-Meyer-Olkin Measure of Sampling Adequacy (KMOMSA). Nilai KMO-MSA yang lebih besar dari 0.60 dianggap sudah cukup baik. Kedua adalah dengan memperhatikan nilaiBartlett test of sphericity, yaitu uji statistic untuk menguji korelasi antar butir yang dapat membentuk satu factor. Ketiga adalah dengan memperhatikan nilai muatan factor (loading factor), yaitu sebuah butir / item dinyatakan merupakan pembentuk factor jika nilai korelasinya lebih besar sama dengan (>=) 0,5 (Hair, et al, 2006, dalam Suryani dan Hendryadi, 2015). Sedangkan pendekatan yang digunakan untuk mengukur reliabilitas instrumen adalah menggunakan koefisien Cronbach Alpha. Parameter yang digunakan didasarkan pada pendapat Nunnaly (1994) yang menyatakan bahwa, suatu instrumen penelitian memiliki reliabilitas yang memadai jika koefisien Cronbach Alpha lebih besar atau sama dengan 0,70.

Tabel 2. Hasil Pengujian Validitas Struktur dan Keandalan Skala

\begin{tabular}{clccc}
\hline \multicolumn{1}{c}{ Skala Workplace Incivility } & $\begin{array}{c}\text { Loading } \\
\text { Factor }\end{array}$ & KMO & $\begin{array}{c}\text { Cronbach } \\
\text { Alpha }\end{array}$ \\
\hline WIC1 & Mendapatkan gosip negatif .... & 0.728 & 0.882 & 0.839 \\
WIC2 & Dijatuhkan atau dipermalukan ... & 0.659 & & \\
WIC3 & Pendapat anda tidak ditanggapi secara serius & 0.768 & & \\
WIC4 & Mendapatkan perkataan kasar & 0.791 & & Cronbach \\
WIC5 & Mendapatkan sebutan atau panggilan ... & 0.738 & & Alpha \\
WIC6 & Hasil kerja anda diragukan & 0.705 & & .792 \\
WIC7 & Melihat rekan berbicara negative .... & 0.647 & Loading & KMO \\
\hline TURN1 & Berpikir untuk meninggalkan .... & Factor & .706 & \\
TURN2 & Mencari informasi pekerjaan lain ... & 0.828 & & \\
TURN3 & Mengirimkan lamaran kerja ke tempat lain & 0.855 & & \\
\hline
\end{tabular}

Sumber: Diolah dengan SPSS

Hasil pengujian validitas pada dua skala menghasilkan kesimpulan bahwa seluruh item yang digunakan telah memenuhi syarat validitas (loading factor $>0.50$ ) yang disyaratkan oleh analisis faktor (Hair, et al. 2006).Pengujian konsistensi internal dengan Cronbach Alpha juga menghasilkan nilai 0.839 untuk workplace incivility dan 0.792 untuk turnover intention.Hasil ini memperlihatkan dua konstrak yang digunakan sudah memenuhi syarat psikometri untuk keandalan yang baik, yaitu di atas 0.70 (Nunnaly, 1994).

\section{Analisis Deskriptif}

Analisis deskriptif seperti ditampilkan pada Tabel 3 yang menunjukkan skor rata-rata untuk workplace incivility sebesar 14.23 dengan standar deviasi 5.21. Sedangkan untuk turnover intention memiliki skor rata-rata sebesar 7.19 dengan standar deviasi sebesar 2.995. Hasil ini menunjukkan bahwa variabilitas data untuk workplace incivility maupun turnover intention relative rendah (std. deviation $<$ mean). 
Tabel 3. Analisis Deskriptif

\begin{tabular}{lccccc}
\hline Variabel & N & Minimum & Maximum & Mean & $\begin{array}{c}\text { Std. } \\
\text { Deviation }\end{array}$ \\
\hline WIC & 300 & 7 & 35 & 14.23 & 5.21 \\
TURN & 300 & 3 & 15 & 7.193 & 2.995 \\
\hline Sum
\end{tabular}

Sumber: Diolah dengan SPSS

\section{Hierarchical moderated regression}

Tahap pertama dalam analisis regresi hierarki adalah menguji perubahan koefisien determinasi dari model yang yang diuji.

Tabel 4. Koefisien Determinasi

\begin{tabular}{ccccc}
\hline Model & $\mathrm{R}$ & R Square & Adj R Square & $\begin{array}{c}\text { Std. Error of the } \\
\text { Estimate }\end{array}$ \\
\hline 1 & $.231^{\mathrm{a}}$ & .053 & .044 & 2.929 \\
2 & $.441^{\mathrm{b}}$ & .195 & .181 & 2.711 \\
3 & $.441^{\mathrm{c}}$ & .195 & .178 & 2.715 \\
\hline
\end{tabular}

a. Predictors: (Constant), marrital, job_tenures, age

b. Predictors: (Constant), marrital, job_tenures, age, WIC, gender

c. Predictors: (Constant), marrital, job_tenures, age, WIC, gender, MOD

Sumber: Diolah dengan SPSS

Tabel 4, di atas menunjukkan nilaipersentasidarivariabilitasvariabel dependenyangdapat dijelaskan oleh semuapredictor secara bersama-sama. Dari tampilan data di atas terlihat perubahanadj. R2 pada tiga model yang diuji yang merupakan carauntuk mengevaluasiseberapa banyakdaya prediksiditambahkan kemodeldengan penambahanvariabel lainpada langkah2 dan seterusnya. Hasil di atas menunjukkan bahwa terjadi peningkatan dari model 1 ke model 2 yaitu sebesar $13.7 \%$ (dari $4.4 \%$ menjadi 18.1\%). Namun model ketiga dibandingkan dengan model ke 2 mengalami penurunan sebesar $0.3 \%$, yaitu dari $18.10 \%$ menjadi $17.8 \%$.Kondisi di atas menunjukkan bahwa penambahan variabel pada model dapat meningkatkan dan menurunkan persentasi koefisien determinasi pada model.

Tabel 5. Evaluasi Model (Uji F)

\begin{tabular}{ccc}
\hline Model & $\mathrm{F}$ & Sig. \\
\hline 1 & 5.572 & $.001 \mathrm{~b}$ \\
2 & 14.214 & $.000 \mathrm{c}$ \\
3 & 11.807 & $.000 \mathrm{~d}$ \\
\hline Sumber: diolah dengan SPSS
\end{tabular}

Dalam Tabel 5, model pertama (hanya menempatkan usia, masa kerja, dan status pernikahan) terlihat bahwa model tersebut adalah signifikan (Sig 0.001>0.05). Hasil yang sama dapat terlihat untuk model kedua dengan menambahkan WIC dan GENDER (Sig. 0.000), dan terakhir model ketiga dengan menambahkan variabel interaksi (WIC x GENDER) memperlihatkan model tetap signifikan (Sig. 0.000).

\section{Pengujian Hipotesis}

Pengujian hipotesis dapat dilihat dalam Tabel 6 pada bagian Model 3. Berdasarkan nilai t hitung diketahui bahwa variabel pada efek utama yaitu WIC signifikan dengan nilai koefisien $\beta=0.392$ dan $\mathrm{t}$ hitung 2.423. Dengan demikian dapat dinyatakan bahwa Hipotesis 1 yang menyatakan bahwa workplace incivility berhubungan positif dengan turnover intention dapat diterima (H1 diterima). Selanjutnya pada pengujian peran gender sebagai moderator dapat dilihat dari nilai koefisien interaksi (MOD) yaitu sebesar $\beta=-0.021$ dan t hitung -0.104 . Hasil ini mengindikasikan bahwa gender tidak terbukti sebagai pemoderator hubungan workplace incivility dengan turnover intention (H2 ditolak). Meski demikian, pada model kedua memperlihatkan bahwa gender memiliki koefisien $\beta=0.106$ 
dengan t hitung 1.979 (signifikan di level 5\%). Temuan ini mengindikasikan bahwa gender meski tidak terbukti sebagai moderator, namun memiliki pengaruh signifikan terhadap turnover intention jika ditempatkan sebagai variabel independen.

Tabel 6. Hasil Regresi Hierarki

\begin{tabular}{lcrrrrrr}
\hline & \multicolumn{2}{c}{ Model 1 } & \multicolumn{2}{c}{ Model 2 } & \multicolumn{2}{c}{ Model 3 } \\
& $\mathrm{b}$ & $\mathrm{t}$ & $\mathrm{b}$ & $\mathrm{t}$ & \multicolumn{1}{c}{$\mathrm{b}$} & \multicolumn{1}{c}{$\mathrm{t}$} \\
\hline Control Var & & & & & & \\
Usia & -0.023 & -0.288 & 0.009 & 0.122 & 0.009 & 0.119 \\
Masa Kerja & -0.061 & -0.848 & -0.065 & -0.982 & -0.065 & -0.974 \\
Status Pernikahan & -0.179 & -2.440 & -0.170 & -2.514 & -0.170 & -2.509 \\
Main Effect & & & & & & \\
WIC & & & 0.376 & 7.108 & 0.392 & 2.423 \\
gender & & 0.106 & 1.979 & 0.121 & 0.780 \\
Interactions & & & & & & \\
MOD (WIC x gender) & & & & & -0.021 & -0.104 \\
\hline
\end{tabular}

Sumber: diolah dengan SPSS

Selanjutnya pengujian hipotesis ke-3 menggunakan teknik analisis independen $\mathrm{t}$-test. Hasil analisis menunjukkan bahwa nilai rata-rata WIC untuk laki-laki adalah sebesar 14.878 dan 13.528 untuk wanita. Nilai $t$ statistic hasil uji beda adalah sebesar 2.257 dan $p$ value 0.025 . Nilai ini mengindikasikan bahwa ada perbedaan signifikan level workplace incivility antara wanita dan lakilaki. Temuan ini memperlihatkan bahwa responden laki-lakile bih sering mendapatkan perilaku tidak sopan dari rekan dan pimpinan dibandingkan responden wanita.

Tabel 7. Hasil uji beda independent t-test

\begin{tabular}{lcccc}
\hline \multicolumn{1}{c}{ Gender } & $\mathrm{N}$ & Mean & t-value & Sig. (2-tailed) \\
\hline Laki-Laki & 156 & 14.878 & 2.258 & 0.025 \\
Wanita & 144 & 13.528 & & \\
\hline
\end{tabular}

Sumber: diolah dengan SPSS

Berdasarkan hasil analisis beberapa temuan yang berhasil dikonfirmasi adalah, pertama, bahwa workplace incivility berhubungan positif dengan turnover intention. Hal ini mengindikasikan bahwa semakin tinggi perilaku ketidaksopanan yang diterima oleh karyawan, maka niat mereka untuk mengundurkan diri akan semakin tinggi. Kesimpulan ini mendukung temuan Lim \& Cortina, (2005); Penney \& Spector, (2005); Rahim \& Cosby, (2015) yang menyatakan bahwa, korban perilaku tidak sopan di tempat kerja cenderung mempertimbangkan untuk meninggalkan organisasi atau secara sukarela mengundurkan diri dari perusahaan.

Hipotesis kedua yang menyatakan gender dapat memoderasi hubungan workplace incivility dengan turnover intention tidak berhasil didukung. Hasil uji statistic menunjukkan bahwa interaksi antara gender dan workplace incivility terbukti tidak signifikan, namun gender sendiri terbukti signifikan mempengaruhi turnover intention jika ditempatkan sebagai variabel independen. Implikasi temuan ini adalah penempatan variabel gender sebagai variabel independen perlu dipertimbangkan untuk penelitian berikutnya.

Hipotesis ketiga, ditemukan perbedaan yang signifikan penerimaan incivility antara laki-laki dan wanita. Hasil analisis memperlihatkan bahwa responden laki-laki melaporkan mendapatkan perilaku tidak sopan lebih tinggi dibandingkan wanita. Temuan ini mendukung sekaligus memiliki perbedaan dengan temuan sebelumnya. Misalnya, ada perbedaan penerimaan incivility antara laki-laki dan wanita sejalan dengan temuan Welbourne et al. (2015); Miner dan Eischeid, (2012); Loi et al. (2013); Cortina,(2008). Namun, penelitian sebelumnya menyebutkan bahwa, wanita lebih memungkinkan menjadi target perilaku tidak sopan di tempat kerja dibanding laki-laki. Hasil penelitian ini justru 
memberikan kesimpulan yang berbeda dimana laki-laki justru lebih sering menjadi korban incivility dari rekan maupun atasan dibandingkan wanita.

\section{SIMPULAN}

Penelitian ini memperlihatkan bahwa pentingnya mempelajari perilaku ketidaksopanan di tempat kerja dan dampak potensial yang ditimbulkannya bagi pria dan wanita dalam hal niat untuk keluar. Temuan penelitian berhasil mengkonfirmasi hasil penelitian sebelumnya bahwa,perilaku ketidaksopanan yang diterima oleh karyawan dapat meningkatkan niat untuk keluar. Gender tidak berhasil dikonfirmasi sebagai variabel moderator, namun dapat menjadi predictor dari niat untuk keluar karyawan. Kesimpulan ketiga adalah ada perbedaan penerimaan perilaku tidak sopan antara karyawan laki-laki dan wanita, dengan laki-laki yang cenderung menjadi target ketidaksopanan tempat kerja. Kesimpulan ketiga ini relative berbeda dengan penelitian sebelumnya yang menyatakan wanita cenderung lebih banyak menjadi target perilaku tidak sopan dibanding laki-laki.

Implikasi temuan ini adalah semua karyawan, baik pria maupun wanita, memiliki hak untuk diperlakukan dengan rasa hormat dan adil di tempat kerja. Selain itu, ketika suatu organisasi dianggap secara implisit atau eksplisit mentoleransi perilaku tidak sopan, hal ini dapat menjadi budaya yang selanjutnya akan membawa dampak negative bagi organisasi dan individu. Perilaku ketidaksopanan tempat kerja yang tidak ditanggapi dengan baik dapat menjadi kebiasaan, terulang kembali dan menciptakan lingkungan kerja yang tidak bersahabat, sehingga dapat menyebabkan tindakan pembalasan dari korban (Andersson dan Pearson, 1999). Situasi semacam itu akan mengarah pada bentuk-bentuk ekstrim perilaku kerja yang kontraproduktif, yang dapat mengakibatkan agresi atau kekerasan. Oleh karena itu, pentingbahwa manajer dan manajemen tingkat atas mengakui keberadaan ketidaksopanan di tempat kerja dan menghentikannya sedini mungkin. Misalnya, untuk mendorong lingkungan kerja yang mengutamakan saling hormat menghormati, maka organisasi harus mendorong suatu nilai budaya yang mengubah dan melarang semua bentuk perilaku tidak sopan antar karyawan, dan antar pimpinan dengan bawahan. Di level manager atau supervisor disarankan untuk secara teratur menghadiri pelatihan komunikasi dan kepemimpinan untuk mempertajam kemampuan mereka untuk memimpin para karyawan.

Mengingat konsekuensi negatif dan tingginya prevalensi ketidaksopanan tempat kerja, penelitian ini dapat berkontribusi sebagai bukti empiris terbaru yang akan memberikan ide kepada para akademisiagar menyelidiki lebih lanjut tentang fenomena tempat kerja sehingga akan membantu, dan mendorong praktisi untuk mengembangkan kebijakan dan langkah-langkah untuk mengurangi kejadian dan dampak yang dialami, disaksikan, dan menjadi korban ketidaksopanan tempat kerja.

\section{Keterbatasan dan saran penelitian mendatang}

Terdapat sejumlah keterbatasan dalam penelitian ini.Pertama adalah masalah keterwakilan. Sampel penelitian ini sebagian besar terdiri dari karyawan yang berusia muda (kurang dari 25 tahun), dan berstatus single (belum menikah), sehingga kemungkinan tidak mewakili nilai dan persepsi untuk karyawan yang berusia lebih senior (di atas 35 tahun). Penelitian mendatang disarankan untuk menggunakan sampel yang lebih bervariasi dengan menambah persentasi karyawan yang berusia di atas 35 tahun. Kedua, penggunaan convenience sampling (metode sampling non-probability) membatasi generalisasi temuan. Disarankan bahwa studi masa depan harus menggunakan sampel acak. Ketiga, penelitian ini hanya berfokus pada pengujian hubungan antara workplace incivility terhadap turnover intention, efek moderasi gender pada hubungan tersebut menggunakan teknik analisis hierarki moderasi, dan pengujian perbedaan workplace incivility antara laki-laki dan wanita dilakukan dengan teknik analisis berbeda. Penelitian mendatang disarankan untuk menggunakan teknik analisis yang sekaligus dapat menampilkan model secara bersamaan, misalnya dengan menggunakan Partial Least Square (PLS) dengan pendekatan multi-group sample.

\section{DAFTAR PUSTAKA}

Andersson, L.M. and Pearson, C.M. (1999), Tit for tat? The spiraling effect of incivility in the workplace, The Academy of Management Review, 24(3), 452-471

Beattie, L. and Griffin, B. (2014), Day-level fluctuations in stress and engagement in response to workplace incivility: a diary study, Work and Stress, 28(2), 124-142 
Bibi, Z., Karim, J. and Din, S. (2013), Workplace incivility and counterproductive work behavior: moderating role of emotional intelligence, Pakistan Journal of Psychological Research, 28(2), 317-334

Chen, Y., Ferris, D. L., Kwan, H. K., Yan, M., Zhou, M., \& Hong, Y. (2013). Self-love's lost labor: A self-enhancement model of workplace incivility. Academy of Management Journal, 56(4), 11991219.

Cortina, L. M., Kabat-Farr, D., Leskinen, E. A., Huerta, M., \& Magley, V. J. (2013). Selective incivility as modern discrimination in organizations: Evidence and impact. Journal of Management, 39(6), 1579-1605.

Cortina, L.M., Magley, V.J., Williams, J.H. and Langhout, R.D. (2001), Incivility in the workplace:incidence and impact, Journal of Occupational Health Psychology, 6(1), 64-80

Cortina, L.M. (2008), Unseen justice: incivility as modern discrimination in organizations, Academy of Management Review, 33(1), 55-75

Cortina, L. and Magley, V. (2009), Patterns and profiles of response to incivility in the workplace, Journal of Occupational Health Psychology, 14(3), 272-288

Ferriss, A. L. (2002). Studying and measuring civility: A framework, trends and scale. Sociological Inquiry, 72(3), 376-392.

Hair, J. F, Black, WC, Babin, BJ, Anderson RE, \& Tatham RL, (2006). Multivariate Data Analisys (Sixth Edition). Upper Saddle River, New Jersey, Prentice Hall, Inc

Hansen, R.J. (1993), Personal harassment in the Canadian force: 1992 survey, Working Paper No. 93-1, Canadian Forces Personnel Applied Research Unit, Willowdale, di kutip dalam Rahim, A., \& Cosby, D. M. (2016). A model of workplace incivility, job burnout, turnover intentions, and job performance.Journal of Management Development, 35(10), 1255-1265.

Holm, K., Torkelson, E. and Backström, M. (2015), Models of workplace incivility: the relationships to instigated incivility and negative outcomes, BioMed Research International, Vol. 11 No. 1, pp. $1-10$.

Hutton, S., \& Gates, D. (2008).Workplace incivility and productivity losses among direct care staff.AAOHN journal, 56(4), 168-175.

Karim, J., Bibi, Z., Rehman, S. U., \& Khan, M. S. (2015). Emotional intelligence and perceived workrelated outcomes: Mediating role of workplace incivility victimization. Pakistan Journal of Psychological Research, 30(1).

Kelly, J., \& McAllister, M. (2013). Lessons students and new graduates could teach: A phenomenological study that reveals insights on the essence of building supportive learning culture through preceptorship. Contemporary Nurse, 4, 170-177

Kim, S.Y., Kim, J.K. and Park, K.O. (2013), Path analysis for workplace incivility, empowerment, burnout, and organizational commitment of hospital nurses, Journal of Korean Academy of Nursing Administration, 19(5), 555-564

Leiter, M. P., Price, S. L., \& Spence Laschinger, H. K. (2010). Generational differences in distress, attitudes and incivility among nurses.Journal of Nursing management, 18(8), 970-980.

Lim, S., Cortina, L.M. and Magley, V.J. (2008), Personal and workgroup incivility: impact on workand health outcomes, Journal of Applied Psychology, 93(1), 95-107.

Lim, S. and Cortina, L.M. (2005), Interpersonal mistreatment in the workplace: the interface and impact of general incivility and sexual harassment, Journal of Applied Psychology, 90(3), 483496 
Loi, N. M., Loh, J. M., \& Hine, D. W. (2015). Don't rock the boat: The moderating role of ender in the relationship between workplace incivility and work withdrawal. Journal of Management Development, 34(2), 169-186.

Miner, K. N., \& Eischeid, A. (2012). Observing incivility toward coworkers and negative emotions: Do gender of the target and observer matter?.Sex Roles, 66(7-8), 492-505.

Montgomery, K., Kane, K. and Vance, C.M. (2004), Accounting for differences in norms of respect: a study of assessments of incivility through the lenses of race and gender, Group \& Organization Management, 29(2), 248-268

Nunnally, J. C., \& Bernstein, I. H. (1994). Psychometric Theory (McGraw-Hill Series in Psychology) (Vol. 3). New York: McGraw-Hill.

Pearson, C. and Porath, C. (2009), The Cost of Bad Behavior: How Incivility Ruins Your Business and What You Can Do about It, Portfolio, New York, NY.

Pearson, C.M. and Porath, C.L. (2005), On the nature, consequences, and remedies of workplace incivility: no time for 'nice'? Think again, Academy of Management Executive, 19(1), 7-18

Penney, L. M., \& Spector, P. E. (2005). Job stress, incivility, and counterproductive work behavior (CWB): The moderating role of negative affectivity. Journal of Organizational Behavior: The International Journal of Industrial, Occupational and Organizational Psychology and Behavior, 26(7), 777-796.

Porath, C.L. and Pearson, C.M. (2012), Emotional and behavioral responses to workplace incivility and the impact of hierarchical status, Journal of Applied Psychology, 42(1), 326-357

Porath, C.L. and Enez, A. (2009), 'Overlooked but not untouched: how rudeness reduces onlookers' performance on routine and creative tasks", Organizational Behavior and Human Decision Processes, 109(1), 29-44

Rahim, A., \& Cosby, D. M. (2016).A model of workplace incivility, job burnout, turnover intentions, and job performance.Journal of Management Development, 35(10), 1255-1265.

Reich, T.G. and Hershcovis, M.S. (2015), Observing workplace incivility and job performance, Journal of Applied Psychology, 100(1), 203-215

Suryani,\& Hendryadi. (2015). Metode Riset Kuantitatif Teori dan Aplikasi Pada Penelitian Bidang Manajemen dan Ekonomi Islam. Jakarta: Prenadamedia Group.

Valle, M., Harris, K., \& Andrews, M. C. (2004). An examination of tenure in negative organizational environments. Journal of Management, 4(2), 113-119

Welbourne, J. L., Gangadharan, A., \& Esparza, C. A. (2016).Coping style and gender effects on attitudinal responses to incivility.Journal of Managerial Psychology, 31(3), 720-738.

Welbourne, J.L., Gangadharan, A. and Sariol, A.M. (2015), Ethnicity and cultural values as predictors of the occurrence and impact of experienced workplace incivility, Journal of Occupational Health Psychology, 20(2), 205-217

\section{PROFIL SINGKAT}

Hendryadi adalah dosen Prodi Manajemen Sekolah Tinggi Ilmu Ekonomi Indonesia Jakarta, dan direktur riset dan konsultasi pada Lembaga Pengembangan Manajemen dan Publikasi (LPMP) Imperium. Penulis memiliki ketertarikan pada penelitian bidang perilaku organisasi, pengembangan skala, dan perbankan syariah. Penulis dapat dihubungi di email: hendry.basrah@gmail.com.

Rachma Zannati adalah dosen Prodi Akuntansi Sekolah Tinggi Ilmu Ekonomi Indonesia Jakarta, serta peneliti di Lembaga Pengembangan Manajemen dan Publikasi (LPMP) Imperium. Penulis memiliki ketertarikan pada penelitian bidang akuntansi serta keuangan, akuntansi syariah, dan perbankan syariah. Penulis dapat dihubungi di email: rachmaznt@gmail.com. 